\title{
The Costumes of Professor Mordecai
}

\section{Winston Weathers}

Dear Ones. I am speaking to you from the top of the apple tree where I am a yellow apple hanging by a silk thread among the plastic leaves of your unnatural innocence. This is the beginning of wisdom: to be what no one else can be. It is eight o'clock. The morning class. I see you crouching in the hard chairs of a tangible reality, and I am amazed at the shapes of your flesh: you are not beautiful at all. You are sick with a terrible youth.

I am not an apple, of course. You would pluck me if I were. I am simply Professor Mordecai. And I stand before you this morning to perform a series of tricks: I firmly believe that all education is trickery, a sleight of hand, a rabbit in the hat, a twisting of mirrors. Behold: a fact. Behold: a judgment. Behold: a premise. Behold: a conclusion. Such a pathetic routine, actually, but I have been scheduled to perform from eight until nine, Mondays, Wednesdays, and Fridays, and old tricks are best, believe me, in the face of sophomores.

Perhaps I could be a kite. I could take beautiful strips of linen, brilliantly blue and brilliantly red, laced to my bird-like arms and I could soar up over the lecture hall. I could catch the wind and rise if only this were an open meadow and there were a spring breeze and there were someone kind enough and gracious enough to hold the kite-string. . . . But where is the meadow and the wind and the charitable student? There is a lesson in all this. I hope you are listening.

The truth is that pedagogy is based upon beautiful costumes. The unicorn. The butterfly. The snail. Yesterday I hid myself in a block of Carrara marble, roughedged and heavy, crying out, "Find the beautiful statue. Chisel and scrape and hammer and you will discover the statue of a god hidden in this hard and heavy truth." But no one looked for my living spirit inside the stone. You wrote, instead, graffiti on the marble planes with lipstick and ball-point pens and mis- 
spelled all the words you should have learned in science class. You misspelled your own names and your own anatomies. I remained in the block of marble, crying out, "Crack open the stone and the form of a man will appear," but you could not hear me speaking.

Yet I know that education is a red-queen's running: yesterday's certainty is today's enigma. I have, therefore, reappeared before you this morning in a new condition. I am wearing the costumes of suicide. You have asked for convincing evidence, and I can think of no better demonstration than self-destruction in the presence of so many witnesses. Will you be shocked by so forceful a gesture in the midst of this lecture? Surely a professor's death will serve as apology for having offended your sensibilities. Which is mostly jargon: my talking like that. I mean simply to shoot myself. I have brought a gun and though I have never destroyed a human life before, I see no reason why I should not begin with myself. You will approve of that. He who can does. He who can't . . . .

I pull the trigger. I fall over the lectern, dangling my limbs on either side, arranging myself as a perfect corpse. And is this not the way we learn? Spreading the dead before us, exhuming the dead before us, dissecting the dead before us? Is this not what you have come for, dear ones? The early-morning autopsy? So you can measure the guts of man and memorize the data and on the examination recite the debris a man becomes when he is no longer living?

No, of course the gun was not loaded. My bowels are bleeding catsup. It is an old trick in academe. I was simply testing you. I find it works better than birds or flowers.

Now for the message: You have asked me for significance. But significance is not my gift. It is yours. I am a demonstration, a performance, a happening of my mind spread out vulgarly in public so that I can make a living. I shall try harder tomorrow, if I am still in existence. I shall try to look at you, to see your relevance to me. You have asked me for everything, but I still refuse to give you my genuine name. And if I do not see anything in your faces, only the sameness of one damn sponge after another, yellowing and sallow with insensible childishness, full of the holes of ignorance, you must remember that my eyes were punctured in last year's reformation and I am blind. I see only visions. And in the darkness of our beautiful community, I have danced my visions in front of you. But you are masturbating. And you do not give a damn.

In a moment, the bell will ring. That brash alarm that marks the end of who I am in front of who you are, and you shall rise as naked now as when you came, though I have thrown my garments over you, thrown the scarves of my performance, the veils of my mind (my stripped and flayed intelligence) into your hands. You are unashamed-and leave all the batiks and silks of civilization trampled at your feet. You are naked, and you tell a lie: you say that you are honest. 
My concluding costume for today shall be that of a Buddhist priest saying a Christian mass. It is a deliberate paradox. It is my custom to end each lecture with a contradiction, and as I genuflect in saffron robes before the chalky altar rail where erasers lie in dumb rows, I draw a Celtic cross upon the blackboard and arrange astrological beasts around it in the shape of a hammer and sickle. I am prodigal with signs, and you are irritated and confused. What do three goats on the elephant's back signify?

It is in my contract with the board of trustees. I must force you to return. And you will come back, thinking I am mad, thinking to surround the citadel of my complete independence and someday storm the walls. But be prepared: Today was an invitation. Tomorrow I plan the apocalypse. And some of you shall go weeping, as Euripides says, into the chambers of a bitter truth. 